$\underline{\text { Original Article }}$

\title{
SYNTHESIS AND EVALUATION OF ANTIMICROBIAL ACTIVITY OF QUINAZOLINONE DERIVATIVES
}

\author{
P. Y. PAWAR, WAGHMARE SWEETI M.* \\ Dr. Vithalrao Vikhe Patil Foundation's College of Pharmacy, Ahmednagar 414111 \\ Email: waghmaresweeti11@gmail.com
}

Received: 21 Jan 2020, Revised and Accepted: 18 Mar 2020

\begin{abstract}
Objective: The present study aims to synthesis and evaluation of antimicrobial activity of quinazolinone derivatives.

Methods: Methyl anthranilate react with acetyl chloride in ethanol gives methyl-2 acetamido benzoate (1) which on reaction with hydrazine hydrate gives 3-amino-2 methyl 4-(3H)-quinazolinone.(2) The amino group of synthesized quinazolinone with substituted acid chloride which gives 3-Chloroacetyl amino-2-methyl-4-quinazolinone (3) which on condensation with various primary amines gives 2-(2-methyl-4-oxo-4H-quinazoline3yl-amino)-N-substituted acetamide (4a-4j).
\end{abstract}

Results: The reaction sequence involves microwave-induced preparation of methyl-2 acetamido benzoate (1) from reaction of Methyl anthranilate react with acetyl chloride in ethanol. Further reaction with hydrazine hydrate gives 3-amino-2 methyl 4-(3H)-quinazolinone. (2) The amino group of synthesized quinazolinone with substituted acid chloride which gives 3-Chloroacetyl amino-2-methyl-4-quinazolinone (3) which on condensation with various primary amines gives 2-(2-methyl-4-oxo-4H-quinazoline-3yl-amino)-N-substituted acetamide (4a-4j).

Which were characterized by IR and ${ }^{1} \mathrm{HNMR}$ spectral data.

Conclusion: All the synthesized compounds were screened for antimicrobial activity by Broth dilution method. Most of the derivatives showed good antimicrobial activity against Gram-Positive and Gram-negative bacteria.

Keywords: Quinazolinone, chloroacetyl chloride, hydrazine hydrate, Microwave irradiation, Spectral studies, Antimicrobial activity.

(C) 2020 The Authors. Published by Innovare Academic Sciences Pvt Ltd. This is an open access article under the CC BY license (http://creativecommons.org/licenses/by/4.0/) DOI: http://dx.doi.org/10.22159/ijcpr.2020v12i3.38318. Journal homepage: https://innovareacademics.in/journals/index.php/ijcpr

\section{INTRODUCTION}

Quinazolinone is a heterocyclic aromatic organic compound. It is an important pharmacophore and a privileged structure in medicinal chemistry. This compound is bicyclic in nature which consist of fusion of benzene ring and a pyrimidine ring. Quinazolinone derivatives were reported to possess analgesic and antiinflammatory activity [1], antimicrobial [2, 3], anticancer [4], anticonvulsant [5], antiviral [6], antioxidant [7], antihypertensive [8], anti-tubercular [9], anthelmintic [10], proton pump inhibitor activity [11]. In this present study Quinazolinone derivatives of Schiff bases containing various primary amine have been synthesized. These synthesized compounds were screened for antibacterial activity by broth dilution method.

\section{MATERIALS AND METHODS}

Melting points of all synthesized compounds were determined in open capillary tubes and were uncorrected. The purity of the compounds was checked by TLC on pre-coated silica gel G plates and visualized in iodine vapour. The IR spectra were recorded on FT-IR 1800 (Perkin-Elmer)spectrophotometer by $\mathrm{KBr}$ pellets technique. ${ }^{1} \mathrm{H}$ NMR spectra were recorded on Jasco 4100 spectrophotometer using DMSO-d6 as solvent and TMS as internal standard.

\section{Synthesis of Methyl 2-Acetoamidobenzoate (I)}

In $100 \mathrm{ml} \mathrm{RBF}$, a solution of Methyl Anthranilate (0.016 mol) in acetyl chloride $(0.127 \mathrm{~mol})$ was refluxed for $15 \mathrm{~min}$. The reaction mixture was cooled, poured into cold water $(50 \mathrm{ml})$ containing a drop of pyridine and stirred until the oil solidifies. Crude product was filtered, washed with cold water and dried it at $1000 \mathrm{C}$. The product was recrystallised from ethanol. Molecular formula $=$ $\mathrm{C}_{10} \mathrm{H}_{11} \mathrm{NO}_{3}$, Molecular weight $=193.19$, Melting Point $=95-98{ }^{\circ} \mathrm{C}, \%$ Yield $=89.6$
Synthesis of 3-amino-2-methyl-4-quinazolinone (II)

\section{Method I (Conventional)}

In $100 \mathrm{ml} \mathrm{RBF}$, a solution of hydrazine hydrate $(10 \mathrm{ml})$ and Methyl 2 -Acetamidobenzoate $(2 \mathrm{gm})$ in ethanol was refluxed for $2 \mathrm{~h}$. The reaction mixture was cooled and stirred into cold water $(50 \mathrm{ml})$. Crude product was filtered, washed with cold water and dried it at 1000C. Crude product was recrystallised from ethanol.

\section{Method II (Microwave)}

In $100 \mathrm{ml} \mathrm{RBF}$, a solution of hydrazine hydrate $(10 \mathrm{ml})$ and $2 \mathrm{gm}$ of Methyl 2Acetoamidobenzoate (I) in ethanol was irradiated at $140 \mathrm{~W}$ for $3 \mathrm{~min}$. The reaction mixture was cooled and stirred into cold water $(50 \mathrm{ml})$. Crude product was filtered, washed with cold water and dried it at 1000C. The product was recrystallised from ethanol. Molecular formula $=\mathrm{C}_{9} \mathrm{H}_{9} \mathrm{~N}_{3} \mathrm{O}$, Molecular weight=175.18 gm, Melting Point $148-150{ }^{\circ} \mathrm{C}, \%$ Yield $=64.33 \%$

Synthesis of 3-Chloroacetyl amino-2-methyl-4-quinazolinone (III)

The mixture of 3-amino-2-methylquinazolin-4(3H)-one (0.01 mole), chloroacetyl chloride ( 0.01 mole) was irradiated under microwave at $700 \mathrm{~W}$ for 23-25 min in presence of TEA using Benzene as solvent. The reaction mixture was cooled and poured into ice-cold water. The resulting solid was filtered, washed with water and recrystallised from ethanol/water. Molecular formula $=\mathrm{C}_{11} \mathrm{H}_{10} \mathrm{~N}_{3} \mathrm{O}_{2} \mathrm{Cl}$, Molecular weight $=251.65 \mathrm{gm}$, Melting Point $120^{\circ} \mathrm{C}, \%$ Yield $=78.3 \%$.

Synthesis of 2-(2-methyl-4-oxo-4H-quinazoline-3yl-amino)-Nsubstituted acetamide (IV)

Equimolar solution of compound 3 (2.08 g) and amine (0.902 g) in methanol $(20 \mathrm{ml})$ with $4-5$ drops of pyridine acid was subjected to microwave irradiation for $15 \mathrm{~min}$. The sample was cooled in an ice bath and TLC was used to monitor the reaction progress. The reaction product was recrystallized with ethanol that gave the final compound. 
Synthesis of 2-(2-methyl-4-oxo-4H-quinazoline-3yl-amino)-Nsubstituted acetamide (IVa-IVj)

The 3-Chloroacetyl amino-2-methyl-4-quinazolinone $(2.08 \mathrm{~g})$ and substituted primary amine $(0.902 \mathrm{~g})$ in methanol $(20 \mathrm{ml})$ with 4-5 drops of pyridine acid was subjected to microwave irradiation for $15 \mathrm{~min}$. The sample was cooled in an ice bath and TLC was used to monitor the reaction progress. The reaction product was recrystallized with ethanol that gave the final compound.

\section{Biological activity}

\section{Antimicrobial activity}

\section{Biological activity Antimicrobial activity}

Synthesized Quinazolinone derivatives $4 \mathrm{a}-4 \mathrm{j}$ were screened for in vitro antibacterial activity against strain of gram-positive (Staphylococcus aureus) and gram-negative (Escherichia coli) bacteria using broth dilution method (MIC) [12]. Ciprofloxacin was used as standard drug for antibacterial activity. The result of antibacterial activity is shown in table 2 .

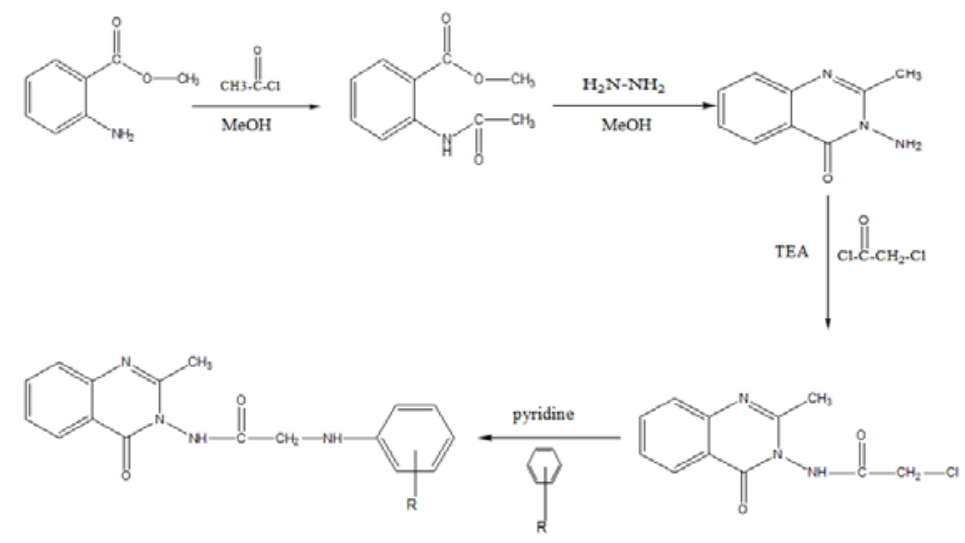

\section{RESULTS AND DISCUSSION}

Methyl anthranilate react with acetyl chloride in ethanol gives methyl-2 acetamido benzoate (1) which on reaction with hydrazine hydrate gives 3-amino-2 methyl 4-(3H)-quinazolinone. (2) The amino group of synthesized quinazolinone with substituted acid chloride which gives 3-Chloroacetyl amino-2- methyl-4-quinazolinone (3) which on condensation with various primary amines gives 2-(2-methyl-4-oxo-4H-quinazoline-3ylamino)-N-substituted acetamide $(4 \mathrm{a}-4 \mathrm{j})$. The physical and analytical data is presented in table 1 . The structures of these newly synthesized compounds were characterized on the basis of IR and1H NMR spectroscopy. The result of spectral data is presented in table 2 .

Table 1: Physical and analytical data of synthesized compounds

\begin{tabular}{|c|c|c|c|c|c|}
\hline Compound code & $-\mathrm{Ar}$ & M. F & M. W & M. pt $^{\circ} \mathrm{C}$ & \% Yield \\
\hline IVa & & $\mathrm{C}_{17} \mathrm{H}_{15} \mathrm{~N}_{5} \mathrm{O}_{4}$ & 353.33 & $279-280(D)$ & 82.66 \\
\hline $\mathrm{IVb}$ & & $\mathrm{C}_{17} \mathrm{H}_{15} \mathrm{~N}_{5} \mathrm{O}_{4}$ & 353.33 & $258-259(\mathrm{D})$ & 55.34 \\
\hline IVc & & $\mathrm{C}_{17} \mathrm{H}_{15} \mathrm{~N}_{5} \mathrm{O}_{4}$ & 353.33 & $278-279(\mathrm{D})$ & 86.79 \\
\hline IVd & & $\mathrm{C}_{17} \mathrm{H}_{15} \mathrm{ClN}_{4} \mathrm{O}_{2}$ & 342.77 & 267-268(D) & 76.23 \\
\hline IVe & & $\mathrm{C}_{18} \mathrm{H}_{18} \mathrm{~N}_{4} \mathrm{O}_{2}$ & 322.36 & 234-235(D) & 62.80 \\
\hline IVf & & $\mathrm{C}_{17} \mathrm{H}_{15} \mathrm{BrN}_{4} \mathrm{O}_{2}$ & 387.23 & 289-290(D) & 64.72 \\
\hline IVg & & $\mathrm{C}_{18} \mathrm{H}_{19} \mathrm{~N}_{5} \mathrm{O}_{2}$ & 337.37 & $230-232(\mathrm{D})$ & 82.43 \\
\hline IVh & & $\mathrm{C}_{17} \mathrm{H}_{17} \mathrm{~N}_{5} \mathrm{O}_{2}$ & 323.34 & $262-263(\mathrm{D})$ & 94.5 \\
\hline IVi & & $\mathrm{C}_{17} \mathrm{H}_{15} \mathrm{ClN}_{4} \mathrm{O}_{2}$ & 342.77 & 280-282(D) & 57.14 \\
\hline $\mathrm{IVj}$ & & $\mathrm{C}_{18} \mathrm{H}_{18} \mathrm{~N}_{4} \mathrm{O}_{2}$ & 322.36 & $279-280(\mathrm{D})$ & 78 \\
\hline
\end{tabular}


Table 2: Spectral data of synthesized compounds

\begin{tabular}{|c|c|}
\hline Compound & Spectral data \\
\hline $\operatorname{IVaIR}\left(\mathrm{cm}^{-1}\right)$ & 3528.16 (C-N Aryl), 3304.43/3299.61 (C-H), 1700.91 (C=0 Amide), 1487 (CH3,1646 (Ar-C=C), 899.91 (C-NO2), 803.20 (Ar-NH) \\
\hline $\operatorname{IVbIR}\left(\mathrm{cm}^{-1}\right)$ & $3503.06(\mathrm{NH}), 3309$ (Aryl C-N), 1456.96 (Amide C=0), $1375.96(\mathrm{C}-\mathrm{H}), 1690$ (Ar C=C), 1001.84 (CH3), 802.2 (C-NO2). \\
\hline $\operatorname{IVcIR}\left(\mathrm{cm}^{-1}\right)$ & 1640.8 (C=0 Amide),1372.1(CH3), 1639.2 (Ar C=C),1706.69 (Aryl C-N), 741.49 (CH3), 804.17(C-H), 622.18 (C-BR) \\
\hline $\operatorname{IVdIR}\left(\mathrm{cm}^{-1}\right)^{1} \mathrm{H}$ & 1350-1000 (ArylC-N), $1688.37(\mathrm{NH}), 1300-800(\mathrm{Ar}-\mathrm{C}-\mathrm{H}), 1455.99(\mathrm{Ar}-\mathrm{C}=\mathrm{C}), 641.13(\mathrm{C}=0$ amide $), 8014.3(\mathrm{C}-\mathrm{Cl})$ \\
\hline $\operatorname{NMR}(\delta)$ & 7.6-8(m, 8H, phenyl), $6.4(\mathrm{~s}, 1 \mathrm{H}, \mathrm{N}-\mathrm{H}$ amide $), 2.5(\mathrm{~s}, 3 \mathrm{H}, \mathrm{Ar}-\mathrm{CH} 3), 1.3(\mathrm{~s}, 1 \mathrm{H},-\mathrm{Cl})$ \\
\hline $\operatorname{IVfIR}\left(\mathrm{cm}^{-1}\right)$ & 3305.39 (C-N), 1329.38 (C-H), 1882.13 (C=O) Amide, 1554.34 (CH3), 1496 (Ar-C=C), $1450.1(\mathrm{C}-\mathrm{NO}), 21487$ (Ar-NH). \\
\hline $\operatorname{IVgIR}\left(\mathrm{cm}^{-}\right.$ & 1687.41 (C-N Aryl), $1632.45(\mathrm{C}-\mathrm{H}), 1443.16(\mathrm{C}=0)$ amide, $1532(\mathrm{CH} 2), 802.242(\mathrm{Ar}-\mathrm{C}=\mathrm{C}), 3305.39(\mathrm{Ar}-\mathrm{NH})$ \\
\hline$\left.{ }^{1}\right) \mathrm{IVe}^{1} \mathrm{H}$ NMR( $\left.\delta\right)$ & $7.8-8.4(\mathrm{~m}, 8 \mathrm{H}$, phenyl $), 6.3(\mathrm{~s}, 1 \mathrm{H}, \mathrm{N}-\mathrm{H}$ amide $), 2.7 \mathrm{~s}, 3 \mathrm{H}, \mathrm{Ar}-\mathrm{CH}_{3} 4.2 \mathrm{~s}, 3 \mathrm{H}, \mathrm{Ar}^{-} \mathrm{CH}_{3}$ \\
\hline
\end{tabular}

4.2 Antimicrobial activity of synthesized compounds (Broth dilution method and MIC)

\begin{tabular}{llll}
\hline S. No. & Compound code & Minimum inhibitory concentration (MIC) microgram & \\
\cline { 3 - 4 } & & Staphylococcus aureus & 15.3 \\
\hline 1 & $4 \mathrm{a}$ & 8.2 & 30.2 \\
2 & $4 \mathrm{~b}$ & 15.3 & 12.0 \\
3 & $4 \mathrm{c}$ & 60.4 & 29.9 \\
4 & $4 \mathrm{~d}$ & 14.6 & 62.8 \\
5 & $4 \mathrm{e}$ & 29.8 & 12.0 \\
6 & $4 \mathrm{f}$ & 32.1 & 62.6 \\
7 & $4 \mathrm{~g}$ & 15.5 & 62.6 \\
8 & $4 \mathrm{~h}$ & 31.2 & 12.0 \\
9 & $4 \mathrm{i}$ & 31.2 & 31.2 \\
10 & $4 \mathrm{j}$ & 15.6 & 31.25 \\
STD & Ciprofloxacin & 15.62 & \\
\hline
\end{tabular}

Table 2: Result of antimicrobial activity

\section{CONCLUSION}

A novel series of Quinazolinone derivatives (4a-4j) were successfully synthesized and characterized by IR, NMR spectroscopy. The final compounds were screened for in vitro antibacterial activity against both Gram-positive and Gram-negative strains of bacteria by broth dilution method. Among all the various derivative, compounds $4 \mathrm{a}$, $4 \mathrm{~b}, 4 \mathrm{~d}, 4 \mathrm{~g}, 4 \mathrm{j}$ showed significant activity against $S$. aureus and E. coli as compared to standard drug Ciprofloxacin.

\section{ACKNOWLEDGEMENT}

Authors are thankful to the Principal, Dr. V. V. P. F's College of Pharmacy, Vilad ghat, Ahmednagar for providing research facilities

\section{FUNDING}

Nil

\section{AUTHORS CONTRIBUTIONS}

All the author have contributed equally.

\section{CONFLICT OF INTERESTS}

The authors declare no conflict of interests.

\section{REFERENCES}

1. Raj K Bansal. Heterocyclic chemistry. 4th ed. New international publisher; 2007.

2. Julio Alvarez Builla, Jose Barluenga. Heterocyclic compounds: an introduction; Modern heterocyclic chemistry. First edition; 2011. p. 1-2.
3. Shadomy S Espinel. A manual of clinical microbiology; American chemical society for microbiology: Washington DC; 1980. p. 647.

4. Stockwell C. Nature's Pharmacy. London, O Goslinka. Antimicrobial activity of United Kingdom. Century Hutchinson Ltd; 1988.

5. Murray PR. ASM Pocket Guide to Microbiology, ASM Press: Washington DC; 1996.

6. Mohamed S Mossad, Kamel M Mohsen, Kaseem MM Emad, Nagesh Abotaleb, Nofal M Salwa, Ahmed F Marwa. Novel 6,8dibromo-4(3H)-quinazolinone derivatives of promising antiinflammatory and analgesic properties. Acta Poloniae Pharm Drug Res 2010;67:159-71.

7. Hosakere D, Revana Siddappa, K Shiva Prasad, L Shiva Kumar l, B Jayalakshmi. Synthesis and biologival activity of new Schiff bases containing $4(3 \mathrm{H})$-quinazolinone ring system. Int J ChemTech Res 2010;2:1344-9.

8. Ponnilavarasan Ilangovan, Swastik Ganguly, Vijay Pandit, James P Stables. Design and synthesis of novel quinazolinone derivatives as broad spectrum anticonvulsant. Scholars Research Liabrary; DePharm Lett 2010. p. 13-21.

9. Journal of enzyme inhibition and medicinal chemistry. Res Gate 2007;220:702-8.

10. V Kasture, SK Wadodkar. Pharmaceutical analysis. Vol. II. Instrumental Methods, Nirali Prakashan; 1995. p. 267, 268, 281, 189, 308, 305, 306.

11. GR Chatwal, SK Anand. Instrumental methods of chemical analysis, Himalaya Publishing House; 1979. p. 2.599-2.616.

12. RM Silverstein, FX Webster. Spectrometric identification of organic compounds, Sixth Edition; 1963. p. 71-109.

13. Shadomy S, Espinel A. Manual of clinical microbiology; America chemical society for microbiology; Washington DC; 1980. p. 647. 